\title{
UNDERSTANDING DISCOURSE COMPETENCE IN TRANSLATION
}

\section{Masduki}

Trunojoyo University

(masdukiunijoyo@yahoo.com)

\begin{abstract}
Discourse as a communication event is influenced by topic being communicated, interpersonal relationship between the communicants, and communication channel used in context. Whatever senses created by the communicants is fully related to culture and situation being involved. Participating in conversation, reading, writing, and translating, activates discourse competence, which requires the use of a set of strategy to realize or mobilize all declarative knowledge in the real context of communication. Further, this article highlights the discourse competence and how it is culturally implemented in translation as an activity of transferring messages. The discussion covers the overview of discourse competence, discourse approach, and discourse competence in translation.
\end{abstract}

Key words: competence; discourse; translation

\section{ABSTRAK}

Wacana sebagai sebuah peristiwa komunikasi dipengaruhi oleh topik yang dikomunikasikan, hubungan interpersonal pihak yang terlibat dalam komunikasi, dan jalur komunikasi yang digunakan dalam suatu konteks. Makna apapun yang diciptakan oleh penutur dalam komunikasi selalu terkait dengan budaya dan situasi yang melingkupinya. Berpartisipasi dalam percakapan, membaca, menulis, dan menerjemahkan, berarti mengaktifkan kompetensi wacana, yang memerlukan penggunaan seperangkat strategi untuk merealisasikan atau memobilisasi semua pengetahuan deklaratif ke dalam konteks komunikasi yang berlangsung. Lebih lanjut, artikel ini mengupas mengenai kompetensi wacana dan bagaimana kompetensi wacana tersebut diterapkan di dalam penerjemahan sebagai suatu kegiatan menyampaikan pesan. Pembahasan dalam artikel ini meliputi pemahaman umum mengenai kompetensi wacana, pendekatan wacana, dan kompetensi wacana dalam penerjemahan.

Kata kunci: kompetens; wacana; penerjemahan

How to Cite: Masduki. (2015). Understanding Discourse Competence in Translation. IJEE (Indonesian Journal Of English Education), 2(1), 76-88. doi:10.15408/ijee.v2i1.1499

Permalink/DOI: http://dx.doi.org/10.15408/ijee.v2i1.1499 


\section{INTRODUCTION}

Translation as a process of transferring a message involves two different languages, the source language (SL) and the target language (TL). The translation also involves two different sociocultural context associated with SL and TL. Therefore, the translation cannot be seen simply as an effort to replace the text of one language into another language. Another factor that is needed in a translation process is a discourse competence to produce a syntactically correct and socially acceptable translation.

Nida and Taber (1974, p. 12) mention that the translation "consists of reproducing in the receptor language the closest natural equivalent of the source language message, first in terms of meaning and secondly in terms of style." It means that translation is an effort to reveal the return message from one language into another language. The phrase receptor language shows that the translation is an activity that is intended for communication and hence the translation is based on whom it is intended and for what purposes it is done.

\section{Discourse Competence}

Discourse competence is one element of communicative competence
(Celce-Murcia et al., 1995, p. 10). The discourse of communication is an event that is affected by the topic being communicated, interpersonal relationships of the parties involved in the communication, and communication channels used in one cultural context. If a person communicates using spoken or written language, he is engaged in a discourse. Any meaning he obtained and created during the communication process is always linked to the cultural context and the context of circumstances. Participating in the conversation, reading, writing, and translating automatically activates the discourse competence and therefore uses a set of strategies or procedures to realize the rules existed in the elements of language in interpreting and expresses the meaning.

Discourse competence can only be acquired if other competencies are obtained. Those competences involve linguistic competence, speech acts competence for spoken language or rhetoric competence for written language (actional competence), sociocultural competence, and strategic competence. Discourse competence refers to the strategy to procedure or 'mobilize' all over declarative knowledge in the context of real communication to create meaning in communication. This capability is 
commonly called procedural knowledge which means that language cannot be broken down into saparated competence (linguistic, actional, sociocutural, strategic, discourse) but is directed toward the acquisition of discourse competence. Acquiring competence in discourse is inseparable from the existence of a context. When one thinks of the language, there are at least three important aspects that must be taken into account, i.e. the context, text, and language system.

Language occurs in a context that can be expressed in such a way that influences, determines, and is linked to the choices of words when creating and interpreting texts. In any context, people use language to perform three main functions namely (1) ideational function which is used to express or construct ideas or information; (2) interpersonal function, which enables people to interact with others; and (3) textual function, the function that regulates how the text is constructed to be cohesive and coherent.

There are two kinds of context i.e. the cultural context and context of the situation. A cultural context 'gives birth' to many kinds of text which is known and accepted by the community members because the arrangement and the language used is to support the communicative purpose of the text. For example, when someone heard the word 'recipe' he/she would imagine the composition of the text and the language commonly used in the recipes. Likewise, if he/she heard the word 'short story' he/she would imagine the composition of the text and the language that is different from the recipes. This text type is called a prose. In short, a cultural context spawned many genres.

When someone learns a foreign language, he/she is involved in the creation and interpretation of various types of text using lexical contents and structure different from those that are produced in his own language system. There are three factors that influence one's language choice, which include the topic (field), interpersonal relationships between the language users (tenor), and lines of communication (mode). These three factors determine whether a person chooses to speak formally or informally. The emphasis on context evolved into an emphasis on discourse. It should be understood that the discourse is more extensive than the text. In translation, it can be said that discourse is the text with all factors that affect meanings, both as a source text and target text. Discourse is the text of the entire context and situation. 
There are various types of discourse, which, among others, can be seen from the communication media and exposure discourse. Based on the communication media, the discourse can be distinguished as oral discourse and written discourse. Referring to the exposure, discourse can be distinguished into several categories, which are discourse as a text, discourse as a genre, discourse as a professional, and discourse as a social practice (Bhatia, 2004, p. 18).

Discourse as a text refers to the use of language that is associated with the level of discourse property. This type of discourse includes formal and functional aspects of a discourse, which are phonology, lexico-grammar, semantics, and other aspects of the structure of the text (for example themes and rheme). This discourse does not refer strictly to the context but solely on a co-text. Although basically a discourse is always associated with a context, discourse as a text often neglects its role in context. Discourse as a text only operates in a textual space where knowledge of language structure and function is being exploited for this. The emphasis on the level of discourse as a text is actually more on the property associated with the textual construction of products rather than interpretation or use of a variety of products.
Discourse as a genre refers to the use of textual products associated with a context, in a broader sense of the text, regarding both how texts are constructed and how it is interpreted and built, and exploited in the context of a particular professional or institutional to achieve certain goals. Thus, this type of discourse is not only concerned with the linguistic features but also socio-cognitive and ethnographic aspects. This framework is sometimes referred to as genre-based theory. Knowledge of genre includes not only textual knowledge but also awareness and understanding of professional practices and community discourse (Swales, 1990). A genre often works on practical space which encourages members of the discourse community to exploit the generic resources to respond to the situational context that is happening. The actual concept of this approach is the discourse as a professional practice, which is basically an extension of the idea of the use of genre related to professional activities. To be able to work effectively at this level, one needs to have professional knowledge and experience of professional practice, and also knowledge of the genre. The workspace of all is the professional space.

Discourse as a social practice refers to the level of interaction with the 
broader social context, where the focus shifted significantly from product to the textual context features, such as changes in participants' identity, social structures or professional relationships, in which a genre needs to be maintained or replaced, and the gain or loss of a genre that brought on a particular reader. Therefore, the discourse as a social practice in the social space requires a person to have a social and pragmatic knowledge in order to work effectively. Communication is difficult to implement in the absence of discourse relations (a relationship between sentences) and without context (Brown, 1994, p. 235). Furthermore, Brown argues that through discourse a person can greet one to another, ask, criticize, and forgive, and so on. Stubb (1983, p. 1) states that the discourse is the language settings above sentences or clauses, such as the exchange of conversation or written texts. Consequently, the use of discourse at the time notices the language used in a social context and in particular the interaction of speakers.

Brown and Yule (1996, p. 1) state that discourse is a complete record of the events of linguistic communication. Communications can use spoken language and written language. Discourse can be transactional and interactional. In this relation, it is explained that the function of language to reveal the contents being described is mentioned as transactional and language functions involved in the disclosure of social relations and personal attitudes described as interactional.

\section{Discourse Approach}

Discourse can be analyzed from several approaches i.e. speech act theory, interactional sociolinguistics, communicative ethnography, pragmatics, analytical conversations, and analysis of variance (Hatch, 1992). Approach of speech acts sees not only the language used to describe the world but also undertakes a number of activities that can be expressed by performance in the speech itself. Interactional sociolinguistic approach in discourse is by looking at the relationships that exist between the social meaning and linguistic meaning. Ethnographic approach involves cultural interpretation in communication. Pragmatic approach involves the meaning of the speaker related to its purpose and the principles of communicative. Analytical conversations uses ethnometodology to look for patterns of uniformity in the context of speech and different social behavior. Variance approach in discourse deals with formal patterns in 
the text, especially narrative and how the patterns are restricted in the text.

Beaugrande and Dressler (1981) developed an approach to discourse using what is called integrative approach. It incorporates various parts of different approaches to jointly look at how the text function in the interaction. Thus, this approach analyzes the text in a more holistic and continuous perspective. Broadly speaking, integrative approach is to analyze whether a text is quite communicative, and to be a communicative, text needs to have textuality consisting of cohesion, coherence, intention, acceptability, informativeness, and situation.

\section{Cohesion}

The presence of discourse cannot be seperated from the context. Discourse context consists of various elements such as situations, the speaker, the listener, time, place, scene, topics, events, channel, code, and forms of message. The elements are closely related to the elements in any proposed language communication (Hymes, 1972) which covers the background, the results / objectives, message, tones, norms, forms, and a variety of languages.

In written discourse, the context is very important to consider. That is because the meaning of a text or its parts are often determined by the sense given by other text. It can be either speech text, paragraphs, or discourse. In addition to the context, discourse is determined by the relationship between elements (cohesion). Halliday and Hasan (1992, p. 65) explains that cohesion is a set of source language as part of the textual metafunction to link one piece of text with other parts. Meanwhile, according to Gutwinski (1976, p. 26), cohesion is the relationship between sentences and between clauses in a text, either in the grammatical level and lexical level.

There are various types of devices cohesion. Halliday and Hasan (1976, p. 5-6) mentions five kinds of cohesion, which are (1) reference, (2) substitution, (3) ellipse, (4) conjunction, and (5) lexical cohesion. Hatch (1992) explains that the cohesion associated with the connection of components of the text that can be seen or heard. These components are the forms and conventions of lexicon and grammar. In closer relation units such as phrases, clauses, and sentences, grammatical relationships formed because of cohesion. However, in the longer text cohesion formed by the repetition of the same word or phrase, repetition of part or the use of two words that have the same root but different word classes, parallelism, or use the same form but 
filled with different expressions, paraphrasing or repetition fill with different expressions, the use of deixis, ellipsis, and conjunction.

\section{Coherence}

Most discourses show the surface forms cohesively with the use of cohesion devices above. However, it is important to note that the surface form of cohesion is not only expressed by simply cohesion but also implies coherence namely the semantic relationships that underlie the discourse. Thus the most important one is the coherence and not merely cohesion. In a discourse, coherence or integrity can be achieved because the author or translator only develops one main idea. Each main idea is expressed by a topic sentence. Furthermore, the topic sentence is often explained by the explanatory sentences. Explanatory sentences do not add new ideas in paragraphs but explained that the idea is summed up in a sentence stub.

\section{Intention}

In contrast to the cohesion and coherence, intentions relate to the attitude of producers who seek to create a cohesive and coherent text so that the goal can be achieved. The ability of this intention can be measured according to the cooperative principles i.e. the maxim of quantity, quality, relevance, and manner. Maxim of quantity assumes that one would give the right amount of information required and would not exceed the required information. Maxim of quality assumes that one should contribute correct information or should not say anything doubtful. Maxim of relevance assumes that one would express the relevance of an existing information to avoid vague and full of ambiguity. Whereas maxim of manner assumes that one would give expression that can be understood by others.

\section{Acceptability}

Acceptability relates to the attitude of the recipient, the recipient's willingness to participate actively in giving meaning to the discourse to achieve a common goal. Giving meaning means that the involvement of reference and inference is important. Reference of a word or sentence is determined by the speaker or writer. Reference is the relationship between phrases in the text and the form of the entity. The term reference is used together with the meanings to discuss the lexical meaning. In that sense, Lyons (as cited in Brown \& Yule, 1996, p. 203) suggested that the term can be replaced by the term of denotation. Halliday and Hasan (1976, p. 37-39) distinguish references on personal 
references, designation reference, and comparative reference.

In addition to the division above, reference can be distinguished by endophoric reference (textual, or in the text) and exophoric reference (which is situational, or outside the text). Endophoric reference distinguishes anaphoric reference and cataphoric reference (Halliday, 1976, p. 33). Anaphoric reference directs the reader to the form, process, or circumstances previously mentioned. Cataphoric reference directs the reader to the next text to identify the elements designated by the reference point. Exophoric reference has a relationship with the interpretation of the word through the situation (circumstances, events, and processes). Unlike the reference, inference is a process that must be done by the listener or reader to understand the meaning which is literally not included in the discourse expressed by the speaker or writer. In other words, the inference is the process of understanding the intention of the speaker or writer.

\section{Informativeness}

Informativeness deals with the extent to which the contents of a text are already expected. The informativeness of text should not exceed so that the text becomes too complicated and conversely the informativeness of text should also not be so low that the text results in boredom. Informativeness of text makes the text covers many new things. Thus boredom can be avoided and the rejection of a text can also be avoided.

\section{Situation}

The situation is related to the factors that make a text relevant to a situation. The situation in which the text is exchanged influences the comprehensiveness of the text.

Situation can affect the means of cohesion. It means that less cohesive text may be more appropriate than more cohesive text depending on the situation. Therefore, in such a matter, economical use of text is more effective and appropriate than a fully cohesive text.

\section{DISCOURSE COMPETENCE IN TRANSLATION}

Hatim and Mason (1997, p. 1) define translation as "an act of communication that attempts to relay, across cultural and linguistic boundaries, another act of communication (which may have been intended for different purposes and different readers/hearers)." Translator in this case is the recipient of the message in the source language and 
when he translates then he acted as a messenger in the target language.

If what is pursued by a translator is the disclosure of the source language in the target language, then the target text must be textually equal to the source text. In the theory of translation, two texts are equal if the contents are similarly understood by the receiver (reader) respectively in the source language and the target language. Therefore, Nida and Taber (1974, p. 174) argue that the best textual translation is "dynamic equivalence" and that the form of source text may be different but having similar meaning, namely that the recipient understands the target text similar to the source text that is understood by the recipient in the source language.

Furthermore, Newmark (1988, p. 4) suggests that how a translation involves the source text and target text at two opposite poles. On the one hand, the source text is mainly influenced by factors namely text-producer, the norm in the source language, culture, and the format of the source language. On the other hand, the target text is also influenced by the same factors namely target text reader, the norm in the target language, culture, and the format of the target language. Thus, an understanding of the text is determined by the context, both in the source language and the target language. This process is called the "dynamics of translation".

Seeing the two different orientations (the source language and the target language), we can see the purpose of translation in a broader perspective. Hoed (2004, p. 1-16) speaks of "foreignizing translation" (which is oriented to the source language) and "domesticating translation" (which is oriented to the target language). In foreignizing translation, the translator is fully under the control of the source language text writer, so that the translator becomes invisible. Here, the role of the author is dominant and the translated text given to the reader is an aspect of "foreign" culture expressed in the language of the reader. In domesticating translation, translator determines what is needed so that the translation is not perceived as the work of "foreign" to the reader. In this case the translator becomes more visible because of his work is considered as a "derivative" even as a sort of "adaptation." Foreignization and domestication can be said to constitute a kind of perspective in translation. It depends on the purpose of translating. Even if this perspective is for making policy in terms of translation of texts, it can be called as ideology. This trend is known as the "Skopos" (Masduki, 2011). 
One example of that is about the title of Mr., Mrs., Mom, and Dad as a foreign colored. Those words, for the adherents of foreignizing translation, are not translated into Indonesian by the reason that the words are no longer alien to Indonesian readers. Similarly, the word sandwich, hotdogs, etc. are not transferred into the target language. It is a concept of foreignizing translation or transference to shift cultural values of the source language into the target language.

Meanwhile, for the adherents of domesticating translation, foreign words, including greetings such as $\mathrm{Mr}$., Mrs., Uncle, Aunt, and so on should be translated into the target language so that the whole translation comes as part of the target language. Similarly, the adaptation of animal story (in which foreign animal figures and natural environment are replaced with animal figures and nature) exists in the target language. The truth of both ideological tendencies cannot be expressed as an absolute. Both have a function in the cultural life of a society.

Newmark (1988, p. 20) argues that the terms of reference for the process of translation is based on the language and cultural issues addressed by involving the context factors that are ultimately followed by the selection of translation procedures. The reference frame is used as the basis of thinking in the translation process, as in the following chart:

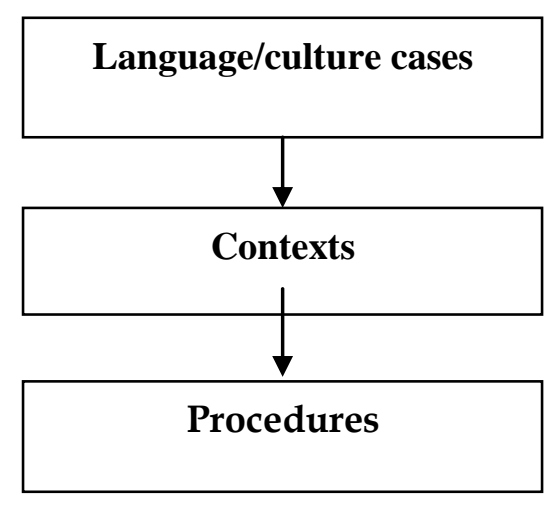

The framework above shows that the factor of context is a way out of the problems arising from the differences between the two languages involved in the translation process. It means that the target language elements that are equivalent to the elements of the source language can be found through the context. So, what is translated is not a formal meaning, but the contextual meaning.

In terms of translation by this discourse, Newmark (1988) gives a translation model based on the characteristics that striking in a text, among others, coherence, cohesion, theme, rheme, enumeration, opposition, conjunction, substitution, comparison, punctuation, and rhetoric. This model also pays attention to the tone, intent, text functions, and pragmatic features in a text. Meanwhile, Hatim and Mason 
(1997) consider translation as a creation and therefore every part of the translated text should be seen as part of the text processing and rhetorical function at a higher level. This means that the translation is something dynamic.

With reference to the model of Newmark, Hatim and Mason, as well as the approach developed by Beaugrande and Dressler, then the source language text can be analyzed or homologized by looking at the sixth aspects of textuality; i.e. cohesion, coherence, intention, acceptability, informativeness, and situation.

Let us take the example text in the source language (English language) as follows:

\section{Go straight ahead then take the first right.}

Cohesion in the text above is built using deixis. Basically there are five kinds of deixis markers namely, person, place, time, discourse, and social (Hatch, 1992) and one of the deixis markers can be found in the text above is deixis of place. This deixis of place explains where the path is: turn right or turn left.

Coherence is associated with the concepts and relationships. Concepts is related to the configuration of knowledge, while the relationship is the link between the concepts that appear in the text. Coherence describes the characteristics of the text as a human activity. A text may not be able to make sense in the absence of interaction between the knowledge conveyed by the text and also human knowledge about the world. Coherence can be built with causality, possibility, reason, time, and location. The text above shows that there is coherence of time and location of the building. The readers, the drivers in this case, understand that he / she should go straight ahead and after the first turn or block, he / she must turn right directly.

Intention in the above text can be viewed based on cooperative principles, namely in terms of quantity and manner. In terms of the quantity, the intention is shown by providing the right information needed by drivers. In terms of manner, the intention is to give expression that can be understood by the drivers.

Acceptability in the text above is to show directions to the driver or other road users before the direction is enacted and the recipients participate in giving meaning to the direction to achieve a common goal. That is, the text as a whole has been able to create a context to provoke the imagination of readers. 
Informativeness in the text indicated by the emergence of a new mental set. In target language (bahasa Indonesia), the emergence of the new mental set is that the Indonesian people rarely see a direction that says if we want to turn, then we must immediately take our turn at first right without following the instructions of traffic signs. This seems strange or even is considered as violating the rules when we drive a car and then turn right directly.

The situation is indicated by factors relating to the condition, in which the situation of the direction is not addressed and even not properly directed in the target language. However, the equivalent translation of the text above is an analogy of the direction to take our turn at first left directly in the road in Indonesia, due to the mental set that the allowed turn is on the left.

\section{CONCLUSION AND SUGGESTION}

From the description above, it can be summarized that the competence of discourse in translation becomes an important aspect to be possessed by the translator. To understand a discourse is not only to understand the meaning of words, the meaning of the syntactic structures, and semantics in general, but also to understand the social and cultural context of the relevant communities where the language is used. The overview of theoretical issues of discourse competence in translation hopefully provide perspectives to translators on how to transfer messages in viewpoint of discourse competence.

\section{REFERENCES}

Beaugrande, R. A. de and Dressler, W. U. 1981. Introduction to Text Linguistics. London: Longman.

Bhatia, V. K. 2004. World of Written Discourse. Advances in Applied Linguistics. London: Continuum.

Brown, H. Douglas. 1994. Principles of Language Learning and Teaching. English Cliffts, New Jersey: Prentice Hall.

Gutwinski, Walderman. 1976. Cohesion in Literary Texts. A Study of Some Grammatical and Lexical Features of English Disocurse. The Hague Mouton.

Halliday, M.A.K \& R. Hasan. 1976. Cohesion in English. London. Longman Group Ltd. 1992. Bahasa, Konteks, dan Teks. Aspek-aspek Bahasa dalam Pandangan Semiotik Sosial. Translation by Asrouddin Barori Tou. Yogyakarta. UGM Pres. 
Hatch, E. 1992. Discourse and Language Education. New York: Cambridge University Press.

Hatim, B. dan I. Mason. 1997. The Translator as Communicator. London/New York: Routledge.

Hoed, Benny H. 2004 "Ideologi dalam Penerjemahan", in Journal of Linguistik Bahasa, Vol.2 no. 1, 2004. PPS UNS.

Hymes, Dell. 1972. Model Interaction of Language and Social Direction in Sosiolinguistics. New York: Holt, Reinhart and Winston Inc

Masduki. 2011 "Konsep Skopos dan Aspek Fungsionalnya dalam Penerjemahan", in Journal of Bahasa dan Seni, no. 2, 2011. UM.
Newmark, Peter. 1988. A Textbook of Translation. UK: Prentice Hall International.

Nida, E.A., dan Ch. Rtaber. 1974. The Theory and Practice of Translation. Helps for Translators. Den Haag: Brill.

Stubbs. Michael. 1983. Discourse Analysis: The Sociolinguistic Analysis of Natural Language. Oxford: Basil Blackwel Pub Ltd.

Swales, J.M. 1990. Genre Analysis: English in Academic and Research Settings. Cambridge: Cambridge University Press. 